\title{
Cytotoxicity, antioxidant and phytochemical screening of propolis extracts from four different Malaysian stingless bee species
}

\author{
Nor Elani Mat Nafi, Nur Basyirah Md Zin, Norzilawati Pauzi, Ammira Shafigha Abdul Khadar, Aulia \\ Rani Anisava, Ainur Awanis Mohd Badiazaman and Khamsah Suryati Mohd*
}

School of Agriculture Sciences and Biotechnology, Faculty of Bioresources and Food Industry, Universiti Sultan Zainal Abidin, Besut Campus, 22200 Besut, Terengganu, Malaysia

*Corresponding author: khamsahsuryati@unisza.edu.my

\section{Article history}

Received 28 December 2018

Revised 22 February 2019

Accepted 4 April 2019

Published Online 15 May 2019

\begin{abstract}
Propolis is a plant-derived substance collected by stingless bee's product from various sources, including plant resins with combination of bee's saliva and wax. Propolis has been used to treat several diseases since ancient times and it is an important source of bioactive natural compound and drug derivatives. The aim of this study was to evaluate biological and chemical profiles of ethanolic extracts from propolis produced by Heterotrigona itama (HI), Geniotrigona thoracica (GT), Lepidotrigona terminate (LT), and Tretrigona apicalis (TA). Cytotoxicity activity was evaluated by using 3-(4,5-Dimethylthiazol-2-YI)-2,5-Diphenyltetrazolium Bromide (MTT) assay against three cancer cell lines. $H$. itama extracts showed the highest cytotoxicity effect with $\mathrm{IC}_{50}$ of $5 \mu \mathrm{g} / \mathrm{mL}$, 4 $\mu \mathrm{g} / \mathrm{mL}$ and $8 \mu \mathrm{g} / \mathrm{mL}$ for MDA-MB-231, SK-UT-1 and HeLa, respectively. Other species only possessed moderate to weak cytotoxicity effect against tested cells. Phytochemical screening was carried out by thin layer chromatography (TLC) analysis and visualized by derivatives agents in order to detect the presence of terpenoids, steroids, saponins, essential oils and phenol. It was found that $H$. itama $(\mathrm{HI})$ possessed the highest antioxidant activity with the lowest $\mathrm{IC}_{50}$ of $30 \mu \mathrm{g} / \mathrm{mL}$ with percetange of inhibition at $85.69 \%$ evaluated by $(2,2-$ diphenyl-1-picryl-hydrazyl-hydrate) DPPH scaveging assay. In conclusion, bee species was considered as important factor in selecting the quality of propolis. It was found that $H$. itama produced the most active extract compared to other species. The data obtained from this study would be the basis for further investigation on therapeutic application especially for cytotoxic activity, antioxidant and phytochemical screenings for four Malaysian stingless bees of propolis.
\end{abstract}

Keywords: Propolis, stingless bee propolis, cytotoxicity, TLC, antioxidant

\section{INTRODUCTION}

Propolis is a complex resinous mixture collected from plant exudates by stingless bees to protect their nest or hive from invader including abiotic factors (Sanpa et al., 2015). They use propolis in thin layer on the internal nest as a defence system by repairing combs to strengthen the thin borders of the comb, including embalming dead bees and intruders in order to protect their hive (Bankova et al., 2000). Propolis resin collected by bees is influenced by three sources including plant exudates, substances that secreted from bee's metabolism, and materials that presented during propolis elaboration (Marcucci, 1995). It is characterized as a lipophilic material, hard and brittle when cold, but soft, pliable and very sticky when in warm condition. Hence, it is named as a bee glue.

The raw propolis is a complex mixture produced by bee-released and plant-derived compound, typically composed of $50 \%$ resins, $30 \%$ waxes, $10 \%$ essential and aromatic oils, $5 \%$ pollen and $5 \%$ of various organic compounds (Park et al., 2002; Pietta et al., 2002; Wagh, 2013; Huang et al., 2014). Propolis has more than 150 constituents and rich in biochemical constituents, including mixture of phenolic, flavonoid aglycones, polyphenols, and ketones (Marcucci, 1995). There are numerous biological properties of propolis that have been reported, for instance anti-bacterial, anti-viral, anti-fungal, anti-ulcer, anti-tumor and anti-inflammatory properties, in which they provide beneficial effects on human health (Szliszka et al., 2009; Wagh, 2013; Chang et al., 2017).

Propolis is used for antibacterial activity by previous study due to its ability to inhibit the growth of various bacteria. The presence of esters, aromatic acids and flavonoids compounds in propolis is good for bactericidal action (Marcucci, 1995). In addition, the presence of esters, flavonoids and phenolics compounds such as caffeic acids and aromatic acid in the propolis will give effect on antiviral activity including the ability to inhibit the reproduction of the influenza viruses A \& B, vaccinia virus and also Newcastle disease virus (Marcucci, 1995). More than that, it can give effect to antifungal activity and inhibit $50 \%$ of HeLa cell growth due to caffeic acid, quercetin and phenyl ester which contained in the propolis resin (Marcucci, 1995).

Bioactive compounds and the color of propolis can vary depending on the diversity of geographical location, plant sources or types of resins and bee species (Huang et al., 2014). The specificity of local flora is responsible for difference species of bees to collect the pollen and thus, the chemical composition of propolis may be different. Malaysia is located at megabiodiversity region and possesses rich flora and fauna 
diversities, including stingless bee species (Sakagami et al., 1990; Norowi et al., 2010). Since 2012 until now, stingless bees have higher production value of propolis of about 66 million per year and became highest demanded due to its nutrition also the medicinal properties (Norowi et al., 2010; Omar et al., 2016). Five species of stingless bees are recorded to be the most abundance species and have commercial value in Malaysia, including Heterotrigona itama, followed by Geniotrigona thoracica, Tetragonula laeviceps, Lepidotrigona terminata and Tetragona apicalis (Salim et al., 2012; Kelly et al., 2014). Stingless bee species namely as H. itama is the most abundance species inhabited in both urban and forest areas (Ab Hamid et al., 2016).

Stingless bees are lacked in functional sting under family Apidae and belong to the tribe Meliponini that commonly used as a pollinator. They have diversity of morphologies, such as nest architecture, habitat, color and body size population which are actively depended on the weather and types of the species (Chinh, \& Sommeijer, 2005; Kelly et al., 2014; Ab Hamid et al., 2016). This meliponini species do not migrate in long distance, show rapid population growth and change their food types to others (Nagamitsu \& Inoue, 2002). The different species of these bees have their own habitat properties and climatic conditions (Ab Hamid et al., 2016). All the four species used in this study have aggressive worker defence (Roubik, 2016). These bees are also known as one of the highly eusocial bees after honey bees and at least 600 stingless bees species belong under 60 genera (Rasmussen \& Cameron, 2009). Stingless bees forage their resources, including pollen, resin and nectar, oil, water, muds and sand particles, in which they utilise the pollen and nectar for food resources while resin is used for constructing their nest (Roubik, 2006; Saufi \& Thevan, 2015). They have specific structure that is located at tibia of hind legs to keep their collected resources (Pangestika et al., 2017).

About 17-32 species of stingless bees are established in Malaysia, yet only two species of them known as H. itama and G. thoracica are mostly used in the meliponiculture and research studies (Kelly et al., 2014). Previous study recorded that $H$. itama and T. terminata preferred tree trunk such as rubber trees and few forest hardwood trees with the range between $71 \mathrm{~cm}$ to $164 \mathrm{~cm}$ while $G$. thoracica preferred tree trunk ranging between $82 \mathrm{~cm}$ to $129 \mathrm{~cm}$ (Kelly et al., 2014). The nest requirement is depended on the types of the stingless bee species. The shapes of nest entrance by H. itama are funnel and round-ringed with a brown or light brown in color, while $L$. terminata has a funnel shape with light brown color for nest entrance. However, the nest entrance of the stingless bee namely $G$. thoracica has a brown or black mountshape entrance with the widest entrance compared to other species that present in Malaysia (Kelly et al., 2014; Saufi \& Thevan, 2015). The nest entrance for L. terminata forms a sticky resin that applied on outside of it (Roubik, 2016).

G. thoracica species is larger species with the body length of $6.67-$ $10.80 \mathrm{~mm}$ (Jalil, 2014; Saufi \& Thevan, 2015) while H. itama is smaller species with body length between $3-7.5 \mathrm{~mm}$ compared to stingless bees (Pangestika et al., 2017). On the other hand, T. apicalis is also relatively small species with $\sim 6 \mathrm{~mm}$ of body size (Schwarz et al., 1937), meanwhile $L$. terminata has medium to large body size of $4.0-5.5 \mathrm{~mm}$ (Pangestika et al., 2017). The species $H$. itama is easily identified in comparison to others by their size and color of their body. Although $H$. itama, G. throcica and T, apicalis have black colored body, H. itama has monotone of color with black colored and uniform sepia tinged wings, while $T$. apicalis and $G$. thoracica have split colored wings with black color at base and white or clear color on the apex region. All species in genus Heterotrigona have a mandible with single tooth towards inner edge (Schwarz et al., 1937). Species namely as $L$. terminata has yellow brownish body on mesoscutellum with tessellation shape on the cuticle, yellow scales on the dorsal and black wings (Jalil, 2014; Pangestika et al., 2017). The morphology of the stingless bee species is different according to different species types as described in Table 1.
Table 1 Morphology of the stingless bee species (Schwarz, 1937; Jalil, 2014).

\begin{tabular}{|c|c|c|c|c|}
\hline Species & $\begin{array}{l}\text { Heterotigona } \\
\text { itama }\end{array}$ & $\begin{array}{l}\text { Geniotrigona } \\
\text { thoracica }\end{array}$ & $\begin{array}{l}\text { Lepidotrigona } \\
\text { terminata }\end{array}$ & $\begin{array}{l}\text { Tetrigona } \\
\text { apicalis }\end{array}$ \\
\hline Mandible & $\begin{array}{c}\text { Single tooth } \\
\text { towards inner } \\
\text { edge of } \\
\text { edentate apex }\end{array}$ & $\begin{array}{c}\text { 1st large, } 2 \text { nd } \\
\text { small } \\
\text { denticle }\end{array}$ & $\begin{array}{l}\text { Big (coarse) } \\
\text { teeth }\end{array}$ & $\begin{array}{l}\text { Two small } \\
\text { (fine) teeth }\end{array}$ \\
\hline $\begin{array}{l}\text { Wing } \\
\text { membrane }\end{array}$ & $\begin{array}{l}\text { Monotone, } \\
\text { black }\end{array}$ & $\begin{array}{l}\text { Dark at base } \\
\text { and clear or } \\
\text { white at apex }\end{array}$ & $\begin{array}{l}\text { Dark at base } \\
\text { and clear or } \\
\text { white at apex }\end{array}$ & $\begin{array}{c}\text { Monotone, } \\
\text { clearly } \\
\text { black }\end{array}$ \\
\hline $\begin{array}{l}\text { Wing humuli } \\
\text { (Some species } \\
\text { may have } \\
\text { asymmetrical of } \\
\text { humuli) }\end{array}$ & $\begin{array}{l}7 \text { on both } \\
\text { wings }\end{array}$ & $\begin{array}{l}9 \text { on both } \\
\text { wings }\end{array}$ & $6-8$ & $\begin{array}{l}7 \text { on both } \\
\text { wings }\end{array}$ \\
\hline Scutellum & Short & Short & Short & Short \\
\hline Propodeum & $\begin{array}{l}\text { Middle } \\
\text { region, } \\
\text { feathery } \\
\text { silver while } \\
\text { tomentum on } \\
\text { each side }\end{array}$ & $\begin{array}{c}\text { Rear of } \\
\text { propodeum } \\
\text { with hairless, } \\
\text { shiny bare } \\
\text { spot }\end{array}$ & $\begin{array}{c}\text { Rear of } \\
\text { propodeum } \\
\text { with hairless, } \\
\text { shiny bare spot }\end{array}$ & - \\
\hline Hind tibia & $\begin{array}{l}\text { Absence of } \\
\text { plumose } \\
\text { hairs }\end{array}$ & $\begin{array}{c}\text { Has plumose } \\
\text { hairs on } \\
\text { posterior rim }\end{array}$ & $\begin{array}{l}\text { Has plumose } \\
\text { hairs on } \\
\text { posterior rim }\end{array}$ & $\begin{array}{l}\text { Has } \\
\text { plumose } \\
\text { hairs on } \\
\text { posterior } \\
\text { rim }\end{array}$ \\
\hline Hind basitarsis & $\begin{array}{c}\text { With silky } \\
\text { patch on } \\
\text { inner face of } \\
\text { hind } \\
\text { basitarsus }\end{array}$ & $\begin{array}{l}\text { No sericeous } \\
\text { patch on hind } \\
\text { basitarsus }\end{array}$ & $\begin{array}{l}\text { No sericeous } \\
\text { patch on hind } \\
\text { basitarsus }\end{array}$ & $\begin{array}{c}\text { No } \\
\text { sericeous } \\
\text { patch on } \\
\text { hind } \\
\text { basitarsus }\end{array}$ \\
\hline Molar space & $\begin{array}{l}\text { Equal to } \\
\text { flagellar } \\
\text { width }\end{array}$ & Very long & $\begin{array}{c}\text { Equal to } \\
\text { flagellar width }\end{array}$ & $\begin{array}{l}\text { Equal to } \\
\text { flagellar } \\
\text { width }\end{array}$ \\
\hline
\end{tabular}

According to the previous study on the nest structure of the stingless bees, the cell arrangement of the nest is in horizontal comb and in a cluster form. The internal nest is made up of brood cells and layers, pollen pots and honey pots (Roubik, 2006). The nest of these bees consists of lying queen, gynes (virgin queen), drones (males) and worker bees. Only the worker bees are involved in the foraging activity while the others are worked on their job at the nest (Saufi \& Thevan, 2015). The nest entrances give in functions to defence their nest from invader, foraging and physio-chemical regulation (Biemeijer et al., 2005; Roubik, 2006). The specific structure of the nest entrance is the arrangement or the thickness of the resin surrounded the internal nest of this species due to the nest age, species types and micro environment factors including abiotic factors and invaders (Roubik, 2006).

Most of these scientific reports of propolis are done on honey bees. Reports on stingless bee are still lacking. Previous study shown that $H$. itama possessed higher antioxidant and antibacterial properties compared to G. thoracica (Ibrahim et al., 2016). These two species also showed different chemical profiles. To the best of our knowledge, there is no report found on therapeutic properties of propolis produced by Lepidotrigona terminate and Tretrigona apicalis. The aim of this study was to investigate the chemical profiles of propolis from different species, namely Heterotrigona itama (HI), Geniotrigona thoracica (GT), Lepidotrigona terminata (LT) and Tretrigona apicalis (TA). This study would also evaluate the antioxidant activity and cytotoxic effect against several tumour cell lines. 


\section{EXPERIMENTAL}

\section{MATERIALS AND METHODS}

\section{Preparation of ethanolic extracts propolis (EEP)}

The extraction method was used and based on the method described by (Szliszka et al., 2009; Xuan et al., 2014) with a slight modification. Each sample was cleaned and frozen in $-20^{\circ} \mathrm{C}$, then ground to powder. Propolis powder was frozen again at $-18^{\circ} \mathrm{C}$ after grinding. The extracts were prepared by mixing $21 \mathrm{~g}$ of crude propolis with $70 \mathrm{~mL}$ of $95 \%$ (v/v) ethanol for at least 3 days at $37^{\circ} \mathrm{C}$, with occasional shaking. The ethanolic extract was filtered through a Whatman filter paper No 1 and dried using rotary evaporator, under reduced pressure at $60{ }^{\circ} \mathrm{C}$. The crude propolis extracts were kept cool $\left(-20^{\circ} \mathrm{C}\right)$ prior analysis. Propolis extracts (EEP) produced by Heterogona itama were coded as HI, Geniotrigona thoracica as GT, Lepidotrigona terminate as LT, and Tretrigona apicalis as TA.

\section{Cell cultures and maintenance}

Cytotoxicity assay was carried out against MDA-MB-231 (ATCC ${ }^{\circledR}$ HTB-26 ${ }^{\mathrm{TM}}$ ), (SK-UT-1ATCC ${ }^{\circledR}$ HTB-114 ${ }^{\mathrm{TM}}$ ) and HeLa (ATCC ${ }^{\circledR}$ CCL-2 ${ }^{\mathrm{TM}}$ ) cell lines. All cells were cultured in DMEM or RPMI 1640 medium, respectively and supplemented with $10 \%(\mathrm{v} / \mathrm{v})$ FBS and $100 \mathrm{U} / \mathrm{mL}$ of penicillin, $100 \mu \mathrm{g} / \mathrm{mL}$ of streptomycin at $37^{\circ} \mathrm{C}$ under humidified $95-5 \%(\mathrm{v} / \mathrm{v})$ air and supplemented with $5 \% \mathrm{CO}_{2}$. Media for cells were replaced every three days and subcultured after cells reaching more that $80 \%$ confluent. The cells were then transferred into culture flask and incubated in humidified at $37^{\circ} \mathrm{C}$ in $5 \% \quad \mathrm{CO}_{2}$ incubator for overnight. Then, in order to maintain and harvest the cells, cells were washed with phosphate buffer saline (PBS) twice and then, old growth media were discarded from flask and trypsin was added into the flask to quickly and gently detach adherent cells. Dislodged cells were incubated for 10 minutes at $37^{\circ} \mathrm{C}$. After that, cells were resuspended into complete medium and transferred into new flask and incubated in $5 \% \mathrm{CO}_{2}$ incubator at $37^{\circ} \mathrm{C}$.

\section{Cell counts}

Hemocytometer was used to count the cells for cytotoxicity test of propolis extracts against three cancer cell lines. Approximately 10-20 $\mu \mathrm{L}$ of cells were placed to the side of coverslip of Neubauer counting chamber. Cell positionings at four large corner squares of the hemacytometer were counted. The number of cells was calculated according the formula below:

$$
\text { Cell no }=\frac{\text { cell no in } 5 \text { squares } x \text { dilution factor } x 10^{4}}{5}
$$

\section{Cell viability assay}

Cytotoxicity effect of EEP was carried out using 3-[4, 5dimethylthiazol-2-yl]-2,5 diphenyltetrazolium (MTT) assay that followed the report by Szliszka et al. (2009) with some modifications. For each of the cell lines, $1 \times 10^{5}$ cell/well was seeded in a $96-$ well plate and incubated at $37^{\circ} \mathrm{C}$ in $5 \% \mathrm{CO}_{2}$ overnight prior to treatment with extracts at various concentrations $(100-0 \mu \mathrm{g} / \mathrm{mL})$. After $72 \mathrm{~h}$ of incubation, $20 \mu \mathrm{L}$ of MTT reagent $(5 \mathrm{mg} / \mathrm{mL})$ was added and incubated for an additional $4 \mathrm{~h}$ at $37^{\circ} \mathrm{C}$. After that, the old media were discarded and $100 \mu \mathrm{L}$ of $100 \%$ DMSO was added to solubilize the formazan crystals. Absorbances were measured at $570 \mathrm{~nm}$ and reference at 630 $\mathrm{nm}$ by microplate reader (Tecan, Switzerland). The concentration of extract that resulted in $50 \%$ growth inhibition $\left(\mathrm{IC}_{50}\right)$ was determined from a graph of percentage of cell viability against the concentration of the extract. Doxorubicin and cisplatin were used as the positive control. The percentage of inhibition was determined using the formula:

$$
\begin{aligned}
& \text { Percentage of inhibition } \\
& =\frac{(\text { OD untreated sample }- \text { OD treated sample })}{(\text { OD untreated sample })} \times 100 \%
\end{aligned}
$$

\section{Phytochemical screening by thin layer chromatography (TLC)}

Propolis extracts were screened for the presence of various classes of compounds according to method by Ibrahim et al., (2016). The extracts were dissolved in $1 \mathrm{~mL}$ of methanol and spotted on thin-layer chromatography (TLC) plates coated with silica gel G (Merck 60F 254 ) of $0.05 \mathrm{~mm}$ thickness. Plates were developed in mobile phase of toluene: ethyl acetate: acetic acid: methanol (8: 2: $0.1: 0.2 \mathrm{v} / \mathrm{v})$. After development and drying, the plates were sprayed with derivatization reagents such as vanillin-sulphuric acid and iodine for detection of the respective classes of compounds.

\section{DPPH (1,1-diphenyl-2-picrylhydrazyl) free radical scavenging assay}

The ability of extracts to scavenge 2,2-diphenyl-1-picrylhydrazyl (DPPH) was determined by DPPH free radical scavenging assay. The scavenging effect of extracts for DPPH was performed and based on the method described by Rosli, et al. (2016) with slight modification. Trolox, water soluble $\alpha$-tocopherol (vitamin E) analogue and Quercetin were served as the standard references. One $\mathrm{mM}$ of DPPH solution was prepared by diluting $5 \mathrm{mg}$ of DPPH in $100 \mathrm{~mL}$ of methanol. Then, 25 $\mu \mathrm{L}$ of standard and sample solution $(500,250,150,125,62.5,31.25$, 15.625 and $7.8125 \mu \mathrm{g} / \mathrm{mL}$ ) were added into a 96 -well plate. Then, 200 $\mu \mathrm{L}$ of $1 \mathrm{mM}$ DPPH solution was mixed into each well and incubated at room temperature in the dark for 30 minutes. After 30 minutes of incubation period, the absorbance was read at $517 \mathrm{~nm}$ by plate reader spectrophotometer. The blank samples used were $50 \mu \mathrm{L}$ of DMSO and $200 \mu \mathrm{L}$ of $1 \mathrm{mM}$ DPPH. The ability of propolis extracts and positive controls to scavenge the DPPH free radical was calculated using the formula, as shown in equation below:

$$
\text { Inhibition } \%=[(\text { A Blank-A Sample }) / \text { A Blank }] \text { x } 100 \%
$$

The lower absorbance was indicated for a higher scavenging activity followed by decreasing the intensity of purple to yellow colour. The radical scavenging activities of crude extracts were compared via $\mathrm{IC}_{50}$ values, in which concentration inhibition that could scavenge the $50 \%$ of DPPH free radical.

\section{RESULTS}

\section{Cytotoxicity effect of propolis extracts produced by different stingless bee species}

Propolis is a complex resinous substance manufactured by stingless bee that collected from natural sources and has various pharmacological properties (Wagh, 2013; Xuan et al., 2014). In order to evaluate the cytotoxicity effect of propolis extracts, the MTT assay was used in this study. The MTT assay is a colorimetric assay based on assessing the cell metabolic activity and linear relationship between metabolically active cells and the color produced, thus allowing an accurate quantification of changes in the rate of cell death or proliferation. SK-UT-1, MDA-MB-231 and HeLa cell lines were used to assess the cytotoxic potential of propolis extracts for initial screening of cell viability. The biochemical mechanism of the MTT assay involves $\mathrm{NAD}(\mathrm{P}) \mathrm{H}$-dependent cellular oxidoreductase enzyme that will convert the yellow tetrazolium MTT [3-(4, 5- dimethylthiazolyl-2)-2,5diphenyltetrazolium bromide] into insoluble (E,Z)-5-(4,5dimethylthiazol-2-yl)-1,3-diphenylformazan (formazan) (Bahuguna, et al., 2017). The formed formazan can be dissolved with dimethyl sulfoxide (DMSO) to give a purple color with characteristic absorption bands at $570 \mathrm{~nm}$ and reference at $630 \mathrm{~nm}$. Intensity of purple color is directly proportional to the cell number and thus, indicating the cell viability. This method is widely used in both cell viability and cytotoxicity tests because it is easy-to-use, safe and has high reproducibility. The MTT assay is the best known method for determining mitochondrial dehydrogenase activities in the living cells.

The cytotoxicity effects of extracts at different concentrations by MTT assay were presented in Figure 1 . The $\mathrm{IC}_{50}$ value was obtained from the plot between the concentrations of extracts versus percent of 
cell viability after $72 \mathrm{~h}$ incubation. The value was used to describe the cytotoxicity effect of extracts towards cell lines. The extracts or compounds were considered to be cytotoxic by American National Cancer Institute when $\left(\mathrm{IC}_{50}\right)$ was less than $30 \mu \mathrm{g} / \mathrm{mL}$ (Suffness \& Pezzuto cited in Halim et al., 2017). From the graph, it was shown that Heterotrigona itama coded as HI showed the highest cytotoxicity effect compared to other species with concentration of extracts required for $50 \%$ inhibition meanwhile the cell viability $\left(\mathrm{IC}_{50}\right)$ was the lowest value for all cell lines with the value of $5 \mu \mathrm{g} / \mathrm{mL}, 4 \mu \mathrm{g} / \mathrm{mL}$ and $8 \mu \mathrm{g} / \mathrm{mL}$ for MDA-MB -231, SK-UT-1 and HeLa (Figure 1 (A), 1 (B) and 1 (C)). While LT showed no cytotoxicity effect against MDA-MB-231 ( IC $_{50}$ $59 \mu \mathrm{g} / \mathrm{mL}$ ) and SK-UT-1( IC $_{50} 45 \mu \mathrm{g} / \mathrm{mL}$ ) (Figure 1 (A) and 1 (B)). Propolis that produced by TA also showed no cytotoxicity effect against HeLa cell line with $\mathrm{IC}_{50}$ of $68 \mu \mathrm{g} / \mathrm{mL}$ (Figure $1(\mathrm{C})$ ). The result of cytotoxic effects against three cancer cells was demonstrated by doxoribucin and cisplatin and shown to be very cytotoxic. The commercial drugs such as doxoribucin and cisplatin were mostly used in treating cancer treatment by chemotherapy to treat any diseases and hence, they were used as a positive control for cell viability test in the present study. Doxoribucin showed $\mathrm{IC}_{50} 1 \mu \mathrm{g} / \mathrm{mL}$ for all cell lines, whereas cisplatin with $\mathrm{IC}_{50}$ of $1 \mu \mathrm{g} / \mathrm{mL}, 2 \mu \mathrm{g} / \mathrm{mL}$ and $4 \mu \mathrm{g} / \mathrm{mL}$ for MDA, SK-UT-1 and HeLa, respectively (Figure 1 (A), 1 (B) and 1 (C)). MTT assay revealed that both HI and GT extracts showed highest cytotoxicity effect against all cancer cell lines, while LT and TA showed no cytotoxic against tested cell lines.

\section{Phytochemical Screening by Thin Layer Chromatography (TLC)}

Thin layer chromatography (TLC) is most common and versatile method for identifying and separating compounds due to its low cost, simplicity, short development time, high sensitivity and good reproducibility. The derivative spray reagents such as vanillinsulphuric acid and iodine vapor were used for detecting compounds presented in the propolis extracts. Table 2 shows the presence of terpenoids, phenols and steroids in propolis extracts when reacting with vanillin-sulphuric acid whereas the presence of both unsaturated and aromatic compounds were detected in all extracts when reacting with iodine vapor in all extracts. However, saponin was absent in GT, LT and TA while it was present in $\mathrm{HI}$

Meanwhile, essential oils were only present in HI and GT but not in LT and TA. Previous report mentioned about the presence of coumarins in propolis methanol extract of Malaysian HI (Ibrahim et al., 2016). However, in this present study, the presence of coumarins was only observed in propolis produced by LT and they were absent in other extracts. Previous study stated that coumarins could be used to treat cancer and resulted in the side effects by radiotherapy (Marshall et al., 1991; Agarwal, 2000).

Overall, the chemical composition of ethanolic propolis extract produced by Heterotrigona itama (HI) was more complex compared to other Malaysian stingless bee species.

Table 1: Phytochemical test (vanillin-sulphuric acid spray reagent and iodine) of the ethanol extracts of propolis produced by stingless bee ,Heterogona itama (HI), Geniotrigona thoracica (GT), Lepidotrigona terminate (LT), and Tretigona apicalis (TA).

\begin{tabular}{|c|c|c|c|c|c|c|}
\hline Constituents & $\begin{array}{c}\text { Color } \\
\text { Detected }\end{array}$ & $\mathrm{HI}$ & GT & LT & $\overline{T A}$ & $\begin{array}{c}\text { Chemical/Spray } \\
\text { Reagent }\end{array}$ \\
\hline Saponins & $\begin{array}{l}\text { Dark } \\
\text { Bluish }\end{array}$ & + & - & - & - & \\
\hline Essential Oils & $\begin{array}{l}\text { Red \& } \\
\text { Brown }\end{array}$ & + & + & - & - & $\begin{array}{l}\text { Vanillin-sulphuric } \\
\text { acid }\end{array}$ \\
\hline Terpenoids & Purple & + & + & + & + & \\
\hline Phenols & $\begin{array}{l}\text { Pink \& } \\
\text { Red }\end{array}$ & + & + & + & + & \\
\hline Steroids & Red & + & + & + & + & \\
\hline Coumarins & Light Blue & - & - & + & - & UV 366 nm \\
\hline $\begin{array}{c}\text { Unsaturated } \\
\text { and Aromatic } \\
\text { Compounds }\end{array}$ & $\begin{array}{l}\text { Yellow- } \\
\text { Brown }\end{array}$ & + & + & + & + & lodine \\
\hline
\end{tabular}

Remarks: +, detected, -, not-detected

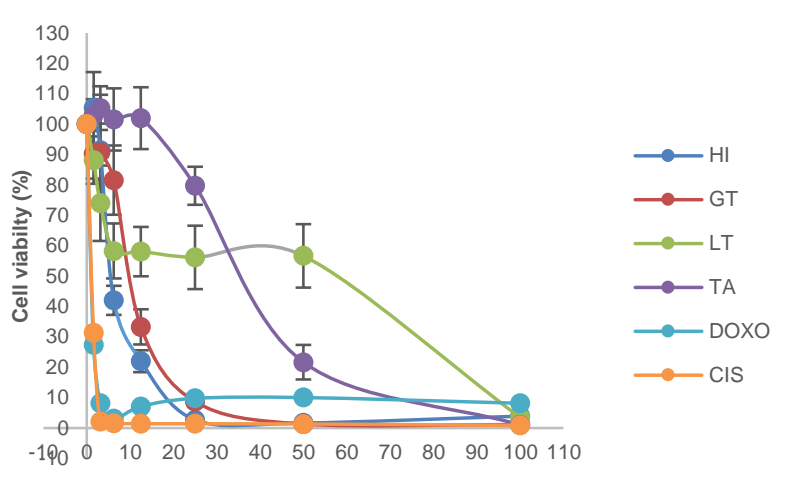

Concentration of propolis extracts $(\mu \mathrm{g} / \mathrm{mL})$

A

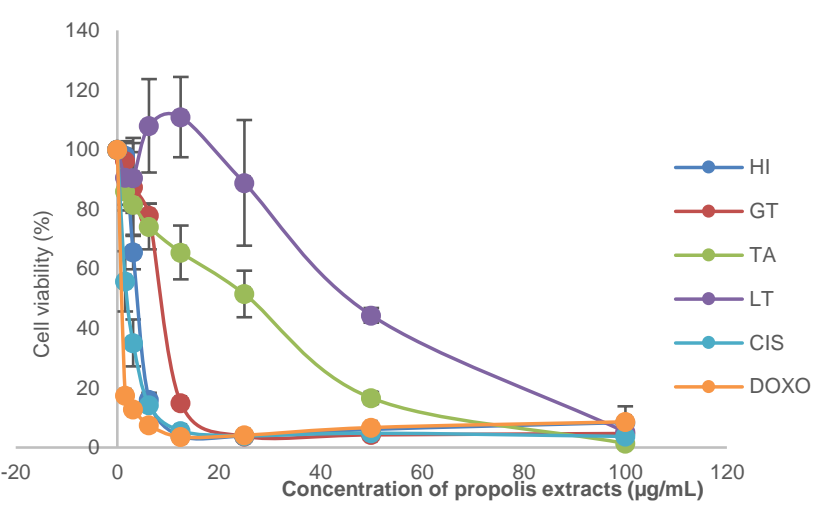

B

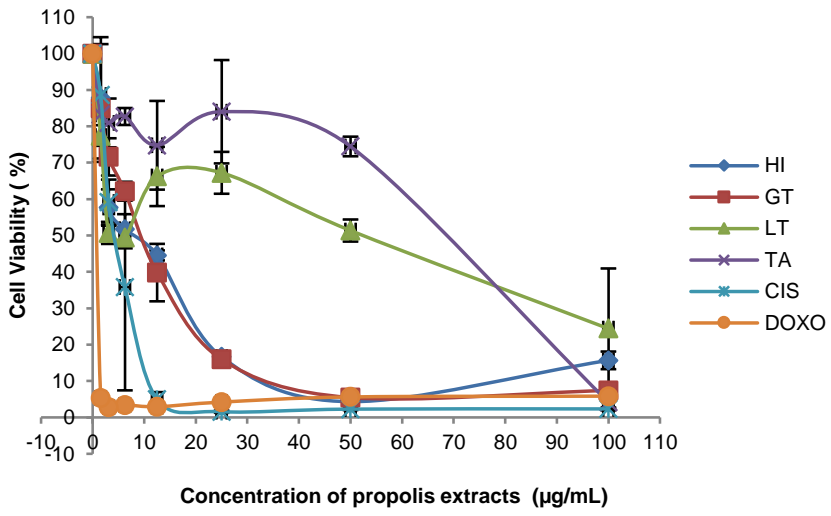

C

Figure 1 Cytotoxicity effect of propolis extracts evaluated using MTT assay against (A) MDA-MB-231 cells (B) SK-UT-1 cells (C) HeLa cells for $72 \mathrm{~h}$ incubation produced by Heterogona itama $(\mathrm{HI})$, Geniotrigona thoracica (GT), Lepidotrigona terminate (LT), and Tretigona apicalis (TA).

\section{DPPH free radical scavenging activity assay}

The antioxidant potential of propolis extracts was determined by using DPPH free radical scavenging assay. This assay has several advantages which are easy to use high sensitivity and enable to analyse large numbers of samples in a short time. The parameter used for this study was $50 \%$ inhibition of the concentration $\left(\mathrm{IC}_{50}\right)$ propolis extracts required to capture the DPPH free radical by scavenging the oxidation reaction chain. The $\mathrm{IC}_{50}$ value was obtained from the graph by the plot $50 \%$ of percentage inhibition versus various concentrations of extracts. Smaller $\mathrm{IC}_{50}$ value of the extract was indicated for the increase in scavenging activity of the DPPH radical, which resulting in increase of antioxidant activity (Ibrahim et al., 2016). In order to measure 
antioxidant activity, a stable free-radical DPPH was used to evaluate the antioxidant activity of HI, GT, LT and TA propolis extracts at concentrations in the range between $(7.8125-500 \mu \mathrm{g} / \mathrm{mL})$ with quercetin and trolox as standard references.

In colorimetric analysis of DPPH for determination of antioxidant activity, HI propolis extract showed the highest antioxidant activity at $\mathrm{IC}_{50}$ of $30 \mu \mathrm{g} / \mathrm{mL}$ and highest percentage of inhibition at $85.69 \%$, followed by GT with $40 \mu \mathrm{g} / \mathrm{mL}$ and $82.22 \%$ at concentration of 150 $\mu \mathrm{g} / \mathrm{mL}$. However, LT showed weak antioxidant activity at $\mathrm{IC}_{50}$ of 128 $\mu \mathrm{g} / \mathrm{mL}$ with $80.47 \%$ of inhibition percentage at concentration of 500 $\mu \mathrm{g} / \mathrm{mL}$. In contrast, TA showed inactive antioxidant activity (Figure 2). Scavenging activity of $\mathrm{HI}$ was most proportional to that of quercetin and trolox with $\mathrm{IC}_{50}$ of $10 \mu \mathrm{g} / \mathrm{mL}$ and $9 \mu \mathrm{g} / \mathrm{mL}$, respectively (Figure 2). However, HI and GT showed antioxidant potential compared to other species. The differences in antioxidant activity could be due to the phenolic, flavonoid or other compound contents of propolis extracts, which were related to the potential antioxidants properties.

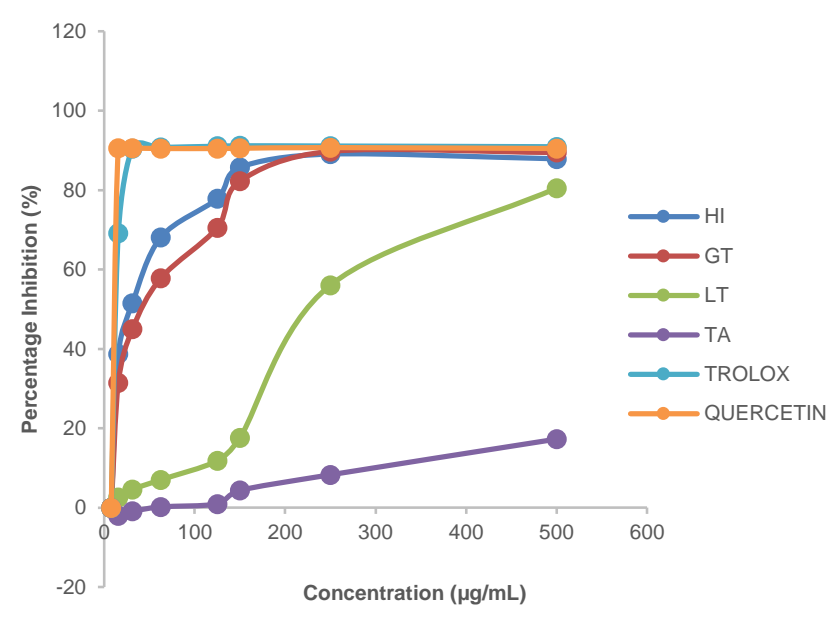

Figure 2. Percentage of DPPH inhibition against concentration of propolis produced by Heterogona itama $(\mathrm{HI})$, Geniotrigona thoracica (GT), Lepidotrigona terminate (LT), and Tretigona apicalis (TA), trolox and quercetin $(\mu \mathrm{g} / \mathrm{mL})$.

\section{DISCUSSION}

This study was first reported on the cell viability assay by four stingless bee propolis ethanol extracts (EEP) against tumor cell lines. The ability of propolis extracts namely $H$. itama $(\mathrm{HI}), G$. thoracica (GT), L. terminata (LT) and T. apicalis (TA) against triple negative breast cancer cells (MDA-MB-231), uterine leiomyosarcoma cells (SKUT-1) and cervical cancer cells (HeLa) was evaluated. Doxorubicin and cisplatin were used as positive control. Doxorubicin is a commercial drug used to treat certain types of bladder, breast, lung, stomach and ovarian cancer (Primeau et al., 2005; Brayfield, 2014) whereas cisplatin is a platinum-based and commonly used in the chemotherapy drug to treat various types of cancers, including small cell lung cancer, ovarian cancer, lymphomas and germ cell tumors (Oun et al., 2018).

The cytotoxicity assay test was found that propolis extract namely Heterotrigona itama coded as HI showed a highest cytotoxicity effect with the lowest concentration of extracts required for 50\% inhibition the cell viability $\left(\mathrm{IC}_{50}\right)$ compared to other species. In contrast, we found that LT extract showed no cytotoxicity effect against MDA-MB231 and SK-UT-1 cell lines while propolis produced by TA also showed no cytotoxicity effect against HeLa cell lines. The different abilities of propolis extracts on cytotoxicity effect against tumor cells might be due to the chemical compound presented in the propolis was different as different types of stingless bee species were existed. The color of propolis and chemical composition from different species were depended on the availability of plant sources and the age of the nest (Brown, 1989; Bankova et al., 2000). The types of local flora and foraging activity were depended on the types of the species of meliponini bees. Therefore, compound presented in the propolis resin was different with the differences in species. They also have timespecific competition with each other for food resources.

The flight intensity of meliponini species to collect food supply was influenced by the time of the day and the abiotic factors (Sajap et al., 2015). As previous study proposed flight intensity of G. thoracica has high tolerance towards weather conditions such as relative humidity, light intensity and air temperature. However, flight intensity by $H$. itama species was highly influenced by light intensity and temperature (Sajap et al., 2015). These two species showed the same flight activity pattern; which actively forage at early morning and reduce in food collected at noon, yet the time of the foraging activity was different. The differences of the time flight activity for both colonies were because of high food resources at the morning (Pierrot \& Schlindwein, 2003) and the low temperature and/or low humidity factors, but higher temperature at noon which reduced the food hunting of the stingless bees for preventing dehydration to occur.

Previous study also claimed that the size of the species was correlated with the types of the plant intake by these species. The smaller size of the stingless bee species preferred the smaller plant due to the ability of this species to enter into floral nectaries to collect the nectar and pollen, while larger species preferred larger plant since they were able to collect large quantities of food resource (Sawatthum et al., 2017). Thus, the chemical composition of propolis was strongly influenced by the source materials, species of bees and types of the extraction.

The chemical composition of ethanolic propolis extract produced by Heterotrigona itama (HI) was more complex compared to other stingless bee species because of the major presence of the chemical compound itself. In contrast, T. apicalis (TA) showed lesser compound presented in the extract. The different chemical compounds contained in all propolis extracts might be due to some species that were preferred to forage at certain plant or flower.

The developed thin layer chromatography (TLC) method is a straightforward and efficient way for screening propolis samples at preliminary stage and for quality purposes. It is significant to qualitatively determine biologically active compounds in propolis using the specific detection reagents. The phytochemical screening of propolis extracts by TLC analysis showed the presence of terpenoids, steroids, saponins, essential oils, phenol, unsaturated and aromatic compounds that visualized by derivatives agents of vanillin-sulphuric acid and iodine vapor. Study by a previous researcher claimed that terpenoid compound was effective against cancer and inflammation due to its ability to block the inhibit proliferation, induce intrinsic apoptosis (targeting Bc12) invasion, and inhibit metastasis (Yadav et al., 2010). Phenolic chemical composition was also reported to exhibit antioxidant activity and anti-proliferative activity, as well as can induce apoptosis (Dolečková et al., 2012; Estévez et al., 2014).

The complex chemical composition contained in HI extract compared to other species, as shown in TLC analysis resulted in highest antioxidant activity by scavenging DPPH method. However, GT also showed good source of antioxidant due to its antioxidant properties. This propolis extracts has the ability to inhibit $50 \%$ of oxidation chain reaction. The reasons behind the different radical scavenging activities exhibited by different types of propolis might due to their specific pollen foraging activities and different diets, which could contribute to the different compounds found in the stingless bee itself (Nagamitsu \& inove, 2002). From this study, we concluded that the chemical composition presented in the propolis extracts was influenced by the types of stingless bee species, resulting in different abilities to inhibit the tested tumour cells and antioxidant activity.

\section{CONCLUSION}

The findings were showed that Heterotrigona itama produced the most active extract in term of cytotoxicity and has potential to be antioxidant agent compared to propolis produced by other Malaysian stingless species. Tests for phytochemical screening by thin layer chromatography (TLC) of four different species of propolis extracts revealed the presence of terpenoids, phenols and steroids but essential 
oils were only presented in Heterotrigona itama $(\mathrm{HI})$ and Geniotrigona throracica (GT), whereas saponin was only presented in Heterotrigona itama $(\mathrm{HI})$ and coumarins were presented in propolis produced by Lepidotrigona terminate (LT). The differences in chemical composition were probably due to the resin plant origin, climate, and resin collection time by the bees. From this study, it was indicated that bee species played a role in determining the chemical and biological profiles of particular propolis and should put into account in decision of further development for propolis.

\section{ACKNOWLEDGEMENT}

This study was funded under the project Investigating Anti-Uterine Fibroid Potential of Malaysia Stingless Bee Propolis and Identification Its Bioactive Markers, grant number FRGS/1/2017/WAB01/UNISZA/02/1.

\section{REFERENCES}

Ab Hamid, S., Salleh, M. S., Krishnan, K. T., Hashim, N. A. 2016. Distribution and morphometrical variations of stingless bees (Apidae: Meliponini) in urban and forest areas of Penang Island, Malaysia. Journal of Tropical Resources and Sustainable Sciences, 4(1), 1-5.

Agarwal, R. 2000. Synthesis \& biological screening of some novel coumarin derivatives. Biochemical Pharmacology, 6, 1042-1051.

Azmi, W. A., Zulqurnain, N. S., Ghazi, R. 2015. Melissopalynology and foraging activity of stingless bees, Lepidotrigona terminata (Hymenoptera: Apidae) from an apiary in Besut, Terengganu. Journal of Sustainability Science and Management, 10(1), 27-35.

Bahuguna, A., Khan, I., Bajpai, V. K., Kang, S. C. 2017. MTT assay to evaluate the cytotoxic potential of a drug. Journal of Bangladesh Pharmacology, 12, 115-118.

Bankova, V. S., de Castro, S. L., Marcucci, M. C. 2000. Propolis: recent advances in chemistry and plant origin. Apidologie, 31(1), 3-15.

Biesmeijer, J. C., Giurfa, M., Koedam, D., Potts, S. G., Joel, D. M., Dafni, A. 2005. Convergent evolution: Floral guides, stingless bee nest entrances, and insectivorous pitchers. Naturwissenschaften, 92(9), 444-450.

Brayfield, A. 2014. Martindale: The Complete Drug Reference. United Kingdom: Pharmaceutical Press.

Brown, R. 1989. Hive products: pollen, propolis and royal jelly. Bee World, 70(3), 109-117.

Chang, H., Wang, Y., Yin, X., Liu, X., Xuan, H. 2017. Ethanol extract of propolis and its constituent caffeic acid phenethyl ester inhibit breast cancer cells proliferation in inflammatory microenvironment by inhibiting TLR4 signal pathway and inducing apoptosis an autophagy. BMC Complementary and Alternative Medicine 17(471), 1-9.

Chinh, T. X., Sommeijer, M. J. 2005. Production of sexuals in the stingless bee Trigona (Lepidotrigona) ventralis flavibasis Cockerell (Apidae, Meliponini) in northern Vietnam. Apidologie, 36(4), 493-503.

Dolečková, I., Rárová, L., Grúz, J., et al. 2012. Antiproliferative and antiangiogenic effects of flavone eupatorin, an active constituent of chloroform extract of Orthosiphon stamineus leaves. Fitoterapia, 83, 1000 1007.

Estévez, S., Marrer, M. T., Quintana, J., Estévez, F. 2014. Eupatorin-induced cell death in human leukemia cells is dependent on caspases and activates the mitogen-activated protein kinase pathway. PloS One, 9(11), e112536.

Halim, N. H., Pauzi, N., Hamil, S. H. R., Shafaei, A., Ismail, Z., Mohd, K. S 2017. Standardization of orthoshiphon stamineus raw material and extracts for anti-uterine fibroid. International Journal of Pharmacognosy and Phytochemical Research, 9(4), 512-515.

Huang, S., Zhang, C. P., Wang, K., Li, G. Q., Hu, F. L. 2014. Recent advances in the chemical composition of propolis. Molecules, 19, 19610-19632.

Ibrahim, N., Mohd Niza, N. F. S., Mohd Rodi, M. M., Zakaria, A. J., Ismail, Z., Mohd, K. S. 2016. Chemical and biological analyses of malaysian stingless bee propolis extracts. Malaysian Journal of Analytical Sciences, 20(2), 413 -

Jalil, A. H. 2014. Beescape for Meliponines: Conservation of Indo-Malayan Stingless Bees. Singapore: Partridge Publishing.

Kelly, N., Farisya, M. S. N., Kumara, T. K., Marcela, P. 2014. Species diversity and external nest characteristics of stingless bees in meliponiculture. Pertanika Journal of Tropical Agricultural Science, 37(3), 293-298.

Marcucci, M. C. 1995. Propolis: Chemical composition, biological properties and therapeutic activity. Apidologie, 26(2), 83-99.

Marshall, M. E., Butler, K., Fried, A. 1991. Screening of synthetic new hetrocyclic derivatives of 3-formyl-4-hydroxy coumarin and evaluated for
Anti-Inflammatory activity in albino rats. Molecular Biotherapy, 3, 158170.

Nagamitsu, T., Inoue, T. 2002. Foraging activity and pollen diets of subterranean stingless bee colonies in response to general flowering in Sarawak, Malaysia. Apidologie, 33, 303-314.

Norowi, M. H., Mohd, F., Sajap, A. S., Rosliza, J., Suri, R. 2010. Conservation and sustainable utilization of stingless bees for pollination services in agricultural ecosystems in Malaysia. In Proceedings of International Seminar on Enhancement of Functional Biodiversity Relevant to Sustainable Food Production in ASPAC, November 9-11 2010 Tsukuba. Japan. (pp. 1-11).

Omar, W. A. W., Azhar, N. A., Fadzilah, N. H., Kamal, N. N. S. N. M. 2016. Bee pollen extract of Malaysian stingless bee enhances the effect of cisplatin on breast cancer cell lines. Asian Pacific Journal of Tropical Biomedicine, 6(3), 265-269.

Oun, R., Moussa, Y. E., Wheate, N. J. 2018. Correction: The side effects of platinum-based chemotherapy drugs: a review for chemists. Dalton Transactions, 47(19), 6645-6653.

Pangestika, N. W., Atmowidi, T., Kahono, S. 2017. Pollen load and flower constancy of three species of stingless bees (Hymenoptera, Apidae, Meliponinae). Tropical Life Sciences Research, 28(2), 179-187.

Park, Y. K., Alencar, S. M., Aguiar, C. L. 2002. Botanical origin and chemical composition of Brazilian propolis. Journal of Agricultural and Food Chemistry, 50(9), 2502-2506.

Pierrot, L. M., Schlindwein, C. 2003. Variation in daily flight activity and foraging patterns in colonies of uruçu-Melipona scutellaris Latreille (Apidae, Meliponini). Revista Brasileira de Zoologia, 20(4), 565-571.

Pietta, P. G., Gardana, C., Pietta, A. M. 2002. Analytical methods for quality control of propolis. Fitoterapia 73(1), 7-20.

Primeau, A. J., Rendon, A., Hedley, D., Lilge, L., Tannock, I. F. 2005. The distribution of the anticancer drug Doxorubicin in relation to blood vessels in solid tumors. Clinical Cancer Research, 11(24), 8782-8788.

Rasmussen, C., Cameron, S. A. 2009. Global stingless bee phylogeny supports ancient divergence, vicariance, and long distance dispersal. Biological Journal of the Linnean Society, 99(1), 206-232.

Roubik, D. W. 2006. Stingless bee nesting biology. Apidologie, 37(2), 124-143.

Rosli, N. L., Roslan, H., Omar, E. A., Mokhtar, N., Abdul Hapit, N. H., Asem, N. 2016. Phytochemical analysis and antioxidant activities of Trigona Apicalis propolis extract. American Institute of Physics, 1791, 020018.

Sajap, A. S., Adam, N. A., Hamid, M. N. 2015. Flight Intensity of two species of stingless bees Heterotrigona Itama and Geniotrigona Thoracica and its relationships with temperature, light intensity and relative humidity. Serangga, 20(1), 35-42.

Sakagami, S. F., Inoue, T., Salmah, S. 1990. Stingless bees of central Sumatra. Stingless bees of central Sumatra, 125-137.

Salim, H. M., Dzulkiply, A. D., Harrison, R. D., Fletcher, C., Kassim, A., Potts, M. D. 2012. Stingless bee (Hymenoptera: Apidae: Meliponini) diversity in dipterocarp forest reserves in Peninsular Malaysia. The Raffles Bulletin of Zoology 2012, 60(1), 213-219.

Sanpa, S., Popova, M., Bankova, V., Tunkasiri, T., Eitssayeam, S., Chantawannakul, P. 2015. Antibacterial compounds from propolis of Tetragonula laeviceps and Tetrigona melanoleuca (Hymenoptera: Apidae) from Thailand. PLoS One, 10(5), e0126886.

Saufi, N. F. M., Thevan, K. 2015. Characterization of nest structure and foraging activity of stingless bee, geniotrigona thoracica (Hymenopetra: Apidae; meliponini). Jurnal Teknologi, 77(33), 69-74.

Sawatthum, A., Jitake, P., Rangyai, O., Prangprayong, R., Pimboon, P., Suparit, K. 2017. Efficacy of stingless bee lepidotrigona terminata as insect pollinator of F1 hybrid cucumber. International Journal, 13(37), 102-106.

Schwarz, H. F., Hobby, B. M., Moore, A. W. 1937. Results of the Oxford University Sarawak (Borneo) Expedition: Bornean stingless bees of the genus Trigona. Bulletin of the AMNH; 73, article 3.

Szliszka, E., Zenon, P., Czuba, Domino, M., Mazur, B., Zydowicz, G., Krol, W. 2009. Ethanolic extract of propolis (EEP) Enhances the apoptosis- inducing potential of TRAIL in cancer cells. Journal of Molecules, 14, 738-754.

Wagh, V. D. 2013. Propolis: A wonder bees product and its pharmacological potentials. Journal of Advances in Pharmacological Sciences, 2013, 308249.

Xuan, H., Li, Z., Yan, H., Sang, Q., Wang, K., He, Q., Wang, Y., Hu, F. 2014. Antitumor activity of chinese propolis in human breast cancer MCF-7 and MDA-MB-231 Cells. Evid Based Complement Alternat Medicine 2014, 280120.

Yadav, V. R., Prasad, S., Sung, B., Kannappan, R., Aggarwal, B. B. 2010. Targeting inflammatory pathway by triterpenoids for prevention and treatment of cancer. Toxins, 2, 2428-2466. 